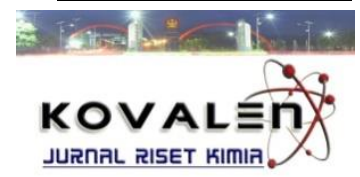

\title{
Review:
}

\section{KAJIAN BIOREMEDIASI PADA TANAH TERCEMAR PESTISIDA}

\author{
[Study of Bioremediation in Polluted Soil of Pesticides] \\ Dwi Juli Puspitasari ${ }^{1 *}$, Khaeruddin $^{1}$ \\ 1) Jurusan Kimia Fakultas MIPA Universitas Tadulako, Palu \\ Jl. Soekarno Hatta, Kampus Bumi Tadulako Tondo Palu, Telp. 0451- 422611
}

Diterima 18 Oktober 2016, Disetujui 24 November 2016

\begin{abstract}
The use of pesticides to eradicate pests are an integral part in farming system. Pesticides use to increase production and protect the production of physical defects can also cause pollution on agricultural land. The presence of pesticide residues in soil and agricultural production can cause health problems for human and animals and even death. To overcome this problem there needs a way to degrade hazardous waste in the environment by performing the remediation. Remediation is carried out by microorganisms fungi, bacteria and algae known as bioremediation. Bioremediation aims to transform compounds into harmless compounds with the end result are carbon dioxide, water and biomass cells. The advantages of bioremediation are environmentally friendly, highly efficient, low cost, can be implemented directly in the field, laboratory and combined with chemical and physical methods.
\end{abstract}

Keywords: bioremediation, soil degradation, pesticides, microorganisms

\begin{abstract}
ABSTRAK
Penggunaan pestisida untuk memberantas hama merupakan bagian tak terpisahkan dalam usaha tani. Penggunaan pestisida selain dapat meningkatkan produksi dan melindungi produksi dari cacat fisik dapat juga menimbulkan pencemaran pada lahan pertanian. Adanya residu pestisida pada tanah dan produksi pertanian dapat menimbulkan masalah kesehatan bagi makhluk lainnya bahkan pada kematian. Untuk mengatasi masalah tersebut perlu ada suatu cara untuk mendegradasi senya wa berbahaya di lingkungan yaitu dengan melakukan remediasi. Remediasi yang dilakukan oleh mikroorganisme jamur, bakteri dan alga disebut sebagai bioremediasi. Bioremediasi bertujuan untuk mengubah senyawa berbahaya menjadi senyawa yang tidak dengan hasil akhir berupa karbon dioksida, air dan sel biomassa. Kelebihannya adalah ramah lingkungan, sangat efisien, biaya yang murah, dapat dilaksanakan langsung di lapangan, dilaboratorium dan digabung dengan metode kimia dan fisika.
\end{abstract}

Kata kunci: bioremediasi, degradasi tanah, pestisida, mikroorganisme 


\section{PENDAHULUAN}

Peningkatan pertumbuhan penduduk membutuhkan peningkatan sektor pertanian yang cepat dan berkelanjutan. Peningkatan sektor pertanian memerlukan berbagai sarana yang mendukung yaitu alat-alat pertanian, pupuk, bahan-bahan kimia termasuk pestisida. Pestisida merupakan bahan kimia atau campuran dari beberapa bahan kimia yang digunakan untuk mengendalikan atau membasmi organisme pengganggu tanaman.

Penggunaan pestisida dewasa ini sudah merupakan bagian yang tidak terpisahkan dari sistem pertanian. Pestisida digunakan sebagai upaya preventif untuk pengendalian hama/penyakit. Permintaan pasar yang menginginkan produksi pertanian tanpa cacat menyebabkan penggunaan pestisida menjadi suatu keharusan untuk mencegah kerusakan tanaman akibat hama. Pestisida kimia merupakan input yang dianggap paling efektif dalam pengendalian hama penyakit. Adanya persepsi petani tentang serangan hama penyakit merupakan penyebab utama kegagalan panen sehingga penggunaan pestisida tidak dapat dihindari. Petani menyebut pestisida sebagai obat sehingga terjadi pemakaian pestisida berlebih-lebihan. Manfaat pestisida yang tinggi sehingga petani memiliki ketergantungan yang tinggi pada pestisida, semakin banyak pestisida digunakan semakin baik karena produksi pertanian semakin meningkat.

Sistem pertanian berbasis bahan high input energi seperti pestisida kimia dapat menyebabkan terjadinya pencemaran lingkungan terutama lingkungan pertanian. Pestisida dapat merupakan agen pencemar yang masuk ke lingkungan baik melalui udara, air maupun tanah dapat berakibat langsung terhadap makhluk hidup maupun lingkungan. Dampak berupa ketidakstabilan ekosistem, adanya residu pada hasil panen dan bahan olahannya, pencemaran lingkungan dan keracunan bahkan kematian pada manusia (Djojosumarto, 2008). Gangguan pestisida akibat adanya residu pada tanah yaitu pada tingkat kejenuhan karena tingginya kandungan pestisida per satuan volume tanah. Sifat pestisida yang persisten sehingga mengalami pengendapan yang lama pada tanah menyebabkan terjadinya degradasi tanah.

Pestisida yang disemprotkan dapat juga bereaksi dengan senyawa lain menjadi senyawa yang lebih kompleks dan tidak mudah terdeteksi. Jika senyawa baru tersebut menjadi senyawa yang lebih toksik, maka akan menjadi potensi bahaya bagi lingkungan termasuk bagi manusia. Adanya residu pestisida pada bahan pertanian dapat berasal dari pengaplikasian langsung pestisida kepada tanaman. Hasil penelitian yang dilakukan oleh Sodiq (2000), Munarso dkk (2009), Stevens dan Kilmer (2009), Tuhumury dkk (2012) dan Sulistyaningsih dkk (2013), 
menyimpulkan masih ditemukan pestisida pada tanaman sayuran, buah-buahan dan organisme tanah. Kontaminasi tanaman dapat juga berasal karena tanaman ditanam pada tanah dimana residu pestisida telah mengalami akumulasi. Hasil penelitian Sani dan Indraningsih (2007) menunjukkan adanya interaksi antara cemaran pestisida pada pakan ternak dan hijauan konsentrat dengan tingkat residu pestisida dalam serum dan jaringan otak sapi. Pestisida tersebut berasal dari tanaman yang ditanam pada tanah yang telah terkontaminasi pestisida.

Bahaya yang ditimbulkan akibat penggunaan pestisida kimia terutama pada tanah jika tidak segera ditangani dapat mengancam lingkungan dan ekosistem lainnya. Bahan pencemar dapat larut karena air hujan dan dapat mencemari daerah-daerah resapan air disekitarnya sehingga perlu upaya untuk menurunkan atau menghilangkan residu pestisida di lingkungan. Salah satu upaya adalah dengan melakukan remediasi. Remediasi dapat diartikan sebagai proses pemulihan dari kondisi yang terkontaminasi oleh cemaran agar bersih kembali yang dapat dilakukan pada media air, udara dan tanah. Penggunaan mikroorganisme dalam proses pemulihan lingkungan tercemar merupakan alternatif pilihan yang ramah lingkungan.

Artikel ini bertujuan untuk mengkaji mengenai bioremediasi pada tanah yang tercemar pestisida mencakup pengertian bioremediasi, degradasi tanah karena penggunaan pestisida, mikroorganisme dalam proses bioremediasi, analisis bioremediasi pada dua golongan pestisida, kelebihan dan kekurangan bioremediasi sehingga dapat memberi masukan untuk pertimbangan dalam memulihkan kondisi lingkungan yang tercemar dengan bahan yang ramah lingkungan. Kajian ini bertujuan untuk menganalisis bioremediasi sehingga dapat dipertimbangkan penggunaannya dalam memulihkan kondisi tanah yang tercemar pestisida. Metoda yang digunakan adalah mengkaji artikel proses bioremediasi dari berbagai jurnal baik nasional maupun internasional.

\section{PENGERTIAN BIOREMEDIASI}

Remediasi merupakan proses dekontaminasi air dan tanah dari senyawa yang berbahaya, seperti hidrokarbon, poliaromatik hidrokarbon (PAH), persistant organic pollutant(POP), logam berat, pestisida dan lain-lain. Proses remediasi yang menggunakan mikroorganisme dikenal sebagai bioremediasi. Bioremediasi adalah proses penguraian limbah organik/anorganik polutan dari sampah organik dengan menggunakan organisme (bakteri, fungi, tanaman atau enzimnya) dalam mengendalikan pencemaran pada kondisi terkontrol menjadi suatu bahan yang tidak berbahaya atau konsentrasinya di bawah batas yang ditentukan oleh lembaga berwenang dengan tujuan mengontrol atau mereduksi bahan pencemar dari 
lingkungan (Munir 2006, Vidali, 2011 dan Singh et al, 2006). Kelebihan teknologi ini ditinjau dari aspek komersil adalah relatif lebih ramah lingkungan, biaya penanganan yang relatif lebih murah dan bersifat fleksibel (Angga, 2011). Bioremediasi pada akhirnya menghasilkan air dan gas tidak berbahaya seperti $\mathrm{CO}_{2}$.

Faktor - faktor yang mempengaruhi proses bioremediasi adalah ; mikroba, Nutrisi dan Lingkungan. Mikroba memiliki kemampuan untuk mendegradasi, mentransformasi dan menyerap senyawa pencemar. Mikroba yang digunakan dapat berasal dari golongan fungi, bakteri, ataupun mikroalga., nutrisi dan lingkungan. Nutrisi, jenis nutrisi yang dibutuhkan bagi mikroba, diantaranya unsur karbon (C), Nitrogen (N), Posfor (P) dan lain lain. ; Lingkungan yang berpengaruh antara lain oksigen, suhu. DO, dan $\mathrm{pH}$.

Kecepatan biodegradasi di tanah tergantung pada empat variabel yaitu:

(i). Ketersediaan pestisida atau metabolit terhadap mikroorganisme.

(ii). Status physiologis dari mikroorganisme

(iii). Perkembangbiakan mikroorganisme pendegradasi pestisida pada lokasi terkontaminasi

(iv). Keberlanjutan populasi mikroorganisme (Singh et al., 2006).

Empat teknik yang dapat digunakan dalam bioremediasi adalah (i) Melakukan stimulasi aktivitas mikroorganisme asli pada lokasi tercemar dengan penambahan nutrient, pengaturan kondis redoks, optimalisasi $\mathrm{pH}$.

(ii) Inokulasi mikroorganisme di lokasi tercemar

(iii) Penerapan immobilized enzyme

(iv) Penggunaan

tanaman (phytoremedisi).

Teknologi bioremediasi ada dua jenis, yaitu ex-situ dan in situ. Ex-situ adalah pengelolaan yang meliputi pemindahan secara fisik bahan-bahan yang terkontaminasi ke suatu lokasi untuk penanganan lebih lanjut. Penggunaan bioreaktor, pengolahan lahan (landfarming), pengkomposan dan beberapa bentuk perlakuan fase padat lainnya adalah contoh dari teknologi exsitu, sedangkan teknologi in situ adalah perlakuan yang langsung diterapkan pada bahan-bahan kontaminan di lokasi tercemar (Vidali 2011).

\section{DEGRADASI TANAH KARENA PENGGUNAAN PESTISIDA}

Tanah sangat penting artinya utamanya bagi usaha pertanian karena kehidupan dan perkembangan tanaman sangat bergantung pada keadaan tanah. Penggunaan tanah untuk usaha-usaha pertanian tanpa diimbangi dengan upaya perbaikan akan menyebabkan degradasi atau kerusakan tanah. Degradasi atau kerusakan tanah adalah hilang atau menurunnya fungsi tanah sehingga tanah 
mengalami penurunan kemampuan untuk berproduktif seperti semula (Arsyad, 2000). Beberapa faktor penyebab tanah terdegradasi dan rendahnya produktivitas, antara lain : deforestasi, mekanisme dalam usaha tani, kebakaran, penggunaan bahan kimia pertanian, dan penanaman secara monokultur (Lal, 2000).

Pestisida merupakan bahan kimia pertanian yang digunakan untuk membasmi Organisme pengganggu tanaman. Setelah aplikasi, residu pestisida akan terdapat pada tanaman, tanah, dan organisme tanah. Menurut Tarumingkeng (1992), hal ini disebabkan lapisan atas tanah memiliki kandungan organik paling banyak sehingga pestisida mudah terabsorpsi, terikat kuat sehingga akan menghambat terjadinya penguapan pestisida. Pestisida yang masuk ke lokasi pertanian juga akan memasuki perairan melalui irigasi, dan dapat berpindah ke tanah di lokasi lain karena aliran air permukaan (runoff). Pestisida akan mengalami proses alam di dalam tanah. Reaksi-reaksi ini dipengaruhi oleh jenis tanah, kelembaban tanah, $\mathrm{pH}$ tanah, temperatur tanah, volatilitas pestisida, mikroorganisme, dan substansi kimia yang terkandung di dalam tanah. Oleh karenanya, laju degradasi satu jenis pestisida tertentu bergantung pada karakteristik fisik tanah, mikroorganisme tanah, dan karakteristik dari pestisida tersebut.

\section{MIKROORGANISME PENDEGRADASI PESTISIDA}

Adanya residu pestisida pada permukaan tanah menyebabkan masalah pada lingkungan. Detoksifikasi lingkungan yang telah mengalami pencemaran dapat dilakukan dengan bioremediasi. Pestisida didegradasi oleh mikroorgisme yang menggunakan sebagai sumber karbon, mineral atau penerima electron dalam rantai respirasi.

Beberapa jamur seperti yang telah dimanfaatkan yakni Trametes hirsutus, Phanerochaete chrysosporium, Phanerochaete sordia dan Cyathusbulleri untuk mendegradasi lindan dan pestisida yang lain Beberapa isolat bakteri murni telah digunakan pestisida spesifik sebagai sumber karbon, nitrogen atau fosfor telah diisolasi (Singh \& Kuhad, 2000). Rosliana (2001), menemukan bahwa penurunan konsentrasi klorpirifos pada tanah terjadi akibat adanya adsorpsi dan degradasi oleh bakteri. Beberapa bakteri aerob genus Bacillus dapat melakukan bioremediasi terhadap tanah yang tercemar klorpirifos, dengan mengurai dan memanfaatkan sebagai sumber energi/nutrien bagi pertumbuhan dan perkembangbiakannya. beberapa bakteri seperti Flavobacterium sp. (Ghassempour et al., 2002), Pseudomonas sp. (Ramanathan and Lalithakumari, 1999), Agrobacterium sp. (Ghassempour et al., 2002; Yasouri, 2006) and Arthrobacter sp. (Ohshiro et al., 1996) dapat menggunakan 
dasinon yang berbahan aktif organofosfat sebagai sumber karbon.

Bakteri dari genus Pseudomonas, diketahui sangat aktif dalam melakukan metabolisme pestisida, banyak organokimia yang mengkontaminasi tanah diketahui telah didegradasi dan digunakan sebagai sumber karbon, termasuk dasinon dan organofosfat lain seperti chlorpyrifos, parathion, Singh et al. (2006) mengisolasi Enterobacter B-14, yang dapat mendegradasi Chlorpyrifos. Yang et al. (2006) dan Li et al. (2007) mengisolasi Stenotrophomonas species and Sphingomonas species berturut-turut yang dapat menggunakan klorpirifos sebagai sumber karbon, fosfor. Ifediegwu et al. (2015), mengisolasi bakteri Pseudomonas aeruginosa, Serretia marcescens and Klebsiella oxytoca dapat digunakan sebagai bioremediasi klorpirifos di tanah yang terkontaminasi. Han et.al, 2015 mengisolasi bakteri Cupriavidus campinensis dapat mendegradasi herbisida asam 2,4-diklorophenoxyacetik

\section{BIOREMEDIASI PESTISIDA}

\section{Bioremediasi pestisida klorpirifos menggunakan bioreactor scale up (Fulekar and Geetha,2008).}

Mikroorganisme adalah kultur murni Pseudomonas Aeruginosa. Medium kultur adalah medium FTW yang terdiri atas .(Herman \&Frankerberger, 1999) (dalam $\mathrm{mg} / \mathrm{l}): 0.255 \quad \mathrm{~K}_{2} \mathrm{HPO}_{4}, 0.255 \mathrm{KH}_{2} \mathrm{PO}_{4}$, $0.255\left(\mathrm{NH}_{4}\right)_{2} \mathrm{SO}_{4}, \quad 0.05 \quad \mathrm{MgSO}_{4} .7 \mathrm{H}_{2} \mathrm{O}$, $0.005 \mathrm{CaCO}_{3}$ and $0.005 \mathrm{FeCl}_{2} .4 \mathrm{H}_{2} \mathrm{O}$ dicampur dengan $1 \mathrm{ml}$ larutan trace element (Focht, 1994). Larutan trace element mengandung (dalam mg/l) 169 $\mathrm{MgSO}_{4} \cdot \mathrm{H}_{2} \mathrm{O}, 288 \quad \mathrm{ZnSO}_{4} \cdot 7 \mathrm{H}_{2} \mathrm{O}, 250$ $\mathrm{CuSO}_{4} .5 \mathrm{H}_{2} \mathrm{O}, 26 \mathrm{NiSO}_{4} .6 \mathrm{H}_{2} \mathrm{O}, 28 \mathrm{CoSO}_{4}$ dan $24 \mathrm{Na}_{2} \cdot \mathrm{MoO}_{4} \cdot 2 \mathrm{H}_{2} \mathrm{O}$.

Peneyiapan pestisida : tabung erlemeyer $250 \mathrm{ml}$ dan kultur nutrient di autoclave selama 20 menit pada $121^{\circ} \mathrm{C}$. $500 \mu l$ acetone mengandung pestisida di sterilkan ditambahkan ke autoclave dan tabung erlemeyer dikeringkan sampai aseton menguap secara komplit. Selanjutnya $100 \mathrm{ml}$ media kultur ditambahkan pestisida sampai sesuai dengan konsentrasi yang diinginkan (Brinch, 2002).

Teknik Scale-up: Satu milliliter subkultured Pseudomonas aeruginosa di inokulasi ke tabung erlemeyer $250 \mathrm{ml}$ yang mengandung media kultur nutrient dengan konsentrasi klorpirifos $10 \mathrm{mg} / \mathrm{l}$. Tabung inokulasi diinkubasi pada orbital shaker pada $160 \mathrm{rpm}, 30^{\circ} \mathrm{C}$ selama 14 hari. Setelah 14 hari $1 \mathrm{ml}$ dari media kultur diambil dan diletakkan pada media kultur dengan konsentrasi pestisida 25 mg/l. Tabung diinmubasi pada skaker pada $160 \mathrm{rpm}, 30^{\circ} \mathrm{C}$ selama 14 hari. Selanjutnya $1 \mathrm{ml}$ dari media kultur ditransfer ke kultur 75 dan 100mg/l, Setiap langkah prosedur melalui pengocokan $160 \mathrm{rpm}, 30^{\circ} \mathrm{C}$ selama 14 hari. Setelah 90 hari perlakuan dihentikan. Setiap 14 hari sampel di pindahkan dan dianalisa menggunakan GC- MS untuk biodegradsi pestisida dan intermediatnya. Pertumbuhan mikrobis dalam tabung 
bioreactor dicatat dengan mengukur absorbans pada $550 \mathrm{~nm}$. Hasil yang diperoleh menunjukkan biodegradasi klorpirifos pada 10, 25 dan 50 mg/l terdegradasi komplit setelah periode 1,5 , 7 hari, berturut - turut. . Intemediate adalah 3, 5, 6 asam trichloro-2-pyridion, 2, 4-bis (1, 1 dimethyiethyl) phenol and 1, 2 zenedicarboxylic selama bioremediasi. Selanjutnya senaywa terse but di konversi menjadi $\mathrm{CO}_{2}$, biomassa dan nutrient.

\section{Bioremediasi pestisida secara in situ (Setiyo et.al., 2011)}

Lahan pertanian yang dibudidayakan tanaman sayuran tomat diberi pupuk kompos kotoran sapi atau tanpa dipupuk kompos (sebagai kontrol) dan pada saat tanaman berusia 1 bulan disemprot pestisida Ditane M-45 dengan konsentrasi $1.2 \mathrm{~g} / / / 20 \mathrm{~m}^{2}$ (dosis redah), $2.4 \mathrm{~g} / / / 20 \mathrm{~m} 2$ (dosis sedang), dan $3.6 \mathrm{~g} / / / 20 \mathrm{~m}^{2}$ (dosis tinggi). Perkembangbiakan bakteri dan kapang diamati pada sampel tanah yang diambil pada kedalaman $0 \mathrm{~cm}, 0-5 \mathrm{~cm}$ dan 5-10 cm, selain itu diamati pula konsentrasi residu pestisida dan kandungan C-organik dan $\mathrm{N}$ organik. Sampel tanah diambil 0, 2, 4, 7, 15, 30, 45, dan 60 hari setelah waktu penyemprotan pestisida. Analisis populasi bakteri dilakukan dengan metode TPC pada media PCA. Pembuatan PCA dengan melarutkan $15 \mathrm{~g}$ agar, $1 \mathrm{~g}$ dextrosa, 5 tripton, $1.5 \mathrm{~g}$ yeast ke dalam $1000 \mathrm{ml}$ aquadest. Larutan tersebut dipanaskan sambil diaduk dengan magnetic stirer sampai mendidih dan homogen. Selanjutnya larutan disterilisasi dalam autoclave pada suhu $121^{\circ} \mathrm{C}$ selama 15 menit. Setelah agak dingin dituangkan ke dalam cawan petri steril \pm 15-20 ml dan didinginkan. Setelah padat cawan petri ditutup dalam posisi terbalik. Metode TPC dilakukan dengan melarutkan $1 \mathrm{~g}$ sampel dengan $9 \mathrm{ml} \mathrm{NaCL}$ faali $(0.9$ \%) ke dalam tabung reaksi. Larutan ini pengencerannya 10-1 dan pengenceran dilakukan sampai 10-6. Setiap kali melakuan pengenceran larutan diaduk menggunakan vortek. Selanjutnya $0.1 \mathrm{ml}$ larutan untuk pengenceran 10-4 sampai 10-6 dituang ke media PCA menggunakan ependorf dari stip steril. Selanjutnya larutan disebar dengan sprider yang telah dicelupkan pad alcohol dan dipanaskan. Kemudian diinkubasi pada suhu ruang selama 48 jam. Koloni yang dihitung hanya yang berjumlah 30-300 koloni. Ekstraksi sampel dilakukan secara langsung. Kadar residu pestisida ditentukan dengan menggunakan Kromatografi gas. Hasil yang diperoleh menunjukkan berdasar pada $\mathrm{C} / \mathrm{N}$, dan $\mathrm{pH}$, dapat menghasilkan solusi yang lebih baik untuk bioremediasi masalah residu pestisida dilakukan dengan mencampurkan kompos dalam pemeliharaan koltikultura. Penyimpangan $\mathrm{pH}$ dalam proses bioremediasi sebesar 0.22 , dan $\mathrm{pH}$ proses bioremediasi in-situ antara 6.9 dan 7.12 atau $\mathrm{pH}$ netral. Pada kondisi ini mikroorganisme akan efektif mengurangi residu pestisida. Proses bioremediasi pada residu pestisida Ditane 
M-45 pada pemeliharaan holtikultura dibagi menjadi $1.2 \mathrm{~g} / / / 20 \mathrm{~m} 2,2.4 \mathrm{~g} / / / 20$ $\mathrm{m} 2$, dan $3.6 \mathrm{~g} / / / 20 \mathrm{~m} 2$ disebar di area secara sempurna, di mana terlihat dari parameter-parameter akan perkembangan populasi mikroorganisme dan jumlah dari residu pestisida. Residu pestisida untuk setiap dosis adalah $0.25-1.7 \%$ pada 35 hari atau nilai ini di bawah 0.003 ppm.

\section{KELEBIHAN DAN KEKURANGAN BIOREMEDIASI.}

Kesuksesan metode bioremediasi ditentukan oleh penggunaan mikroba yang tepat, di tempat yang tepat dengan faktorfaktor lingkungan yang tepat untuk terjadinya degradasi. Kelebihan bioremediasi adalah dapat dilakukan pada lokasi (perlakuan lapangan) kurangnya biaya dan gangguan Bioremediasi dapat menghilangkan polutan secara permanen dan dapat diterima masyarakat, dengna didukung peraturan dapat digabung dengan metode perlakuan fisika dan kimia (Rani dan Dania, 2014).

Bioremediasi mempunyai keterbatasan (Singh et al., 2006). Residu yang dihasilkan merupakan senyawa yang tidak berbahaya meliputi CO2, air, dan sel biomassa. Banyak senyawa yang dianggap berbahaya dapat dirubah menjadi tidak berbahaya dan memindahkan kontaminan dari satu medium lingkungan ke tempat lain.

Strategi yang dapat dilakukan untuk meningkatkan kemampuan mendegradasi polutan yaitu : menggunakan sel mikroba untuk mengantar gen melalui konyugasi dan menambahkan gen yang sebenarnya ke tanah (Singh et al., 2006)

\section{KESIMPULAN}

Bioremediasi dapat digunakan untuk menghilangkan polutan pestisida secara permanen di tanah menggunakan mikroorganisme. Mikroorganisme yang digunakan dapat dari golongan jamur ataupun bakteri. Faktor yang perlu diperhatikan ketika melakukan bioremediasi adalah jenis mikroorganisme yang akan digunakan, lokasi dan faktorfaktor lingkungan yang mempengaruhi proses bioderadasi. Hasil akhir dari proses remediasi adalah $\mathrm{CO}_{2}$, air, dan sel biomassa.

\section{DAFTAR PUSTAKA}

Angga, 2011, Konservasi Tanah dan Remediasi dalam http://angga. staff.ipb. ac.id/files/2011/04/10Konservasi-Tanah-Remediasi.pdf, diakses tangal 29 november 2016.

Arsyad, S., 2000, Konservasi Tanah dan Air, Bogor : IPB Press.

Brinch UC, Ekelund F, Jacobsen CS, 2002. Method for spiking soil samples with organic compounds. $J$. Applied and Environmental Microbiology. 68 (4):1808-1816.

Djojosumarto, P. 2008. Panduan Lengkap Pestisida dan Aplikasinya. Jakarta : Agromedia Pustaka.

Fulekar, MH., Geetha, M. 2008. Bioremediation of chlorpyrifos by Pseudomonas aeruginosa using scale up technique. J. Appl. Biosci., 12: $657-660$.

Ghassempour A, Mohammadkhah A, Najafi F, Rajabzadeh M. 2002. Monitoring of the pesticide diazinon in soil, stem and surface water of rice fields. Anal Sci.18(7):779-83.

Ifediegwu, M.C., Agu, K.C., Awah, N.S., Mbachu, A.E., Okeke, C.B., Anaukwu, C.G., Uba, P.O., Ngenegbo, U.C., 
Nwankwo, C.M., $2015 . \quad$ Isolation, Growth and Identification of Chlorpyrifos Degrading Bacteria from Agricultural Soil in Anambra State, Nigeria, Universal Journal of Microbiology Research 3(4).

Lal. 2000. Soil management in the developing countris. Soil Science. 165(1):57-72

$\mathrm{Li}, \mathrm{X}$; ; He, J.; and Li, S. 2007. Isolation of Chlorpyrifos Degrading Bacterium, Shengomonas sp, strain DSP-2 and Cloning of the MPD Gene. Research Microbiology, 158: 143-149.

Munarso, S., J Miskiyah,., , dan Broto, W., 2009. Studi Kandungan Residu Pestisida Pada Kubis, Tomat, Dan Wortel Di Malang Dan Cianjur. Buletin Teknologi Pascapanen Pertanian: Vol. 5. http://pascapanen. litbang.deptan.go. id/assets/media/ publikasi/bulletin/2009_4.pdf,diakses 12 Desember 2012.

Munir, E. 2006. Pemanfaatan Mikroba dalam Bioremediasi: Suatu Teknologi Alternatif untuk Pelestarian Lingkungan. Medan: USU.

Ohshiro, K., Kakuta, T., Sakai, T., Hirota, H., Hoshino, T., Uchiyama, T., 1996. Biodegradation of organophosphorus insecticides by bacteria isolated from turf green soil. J. Ferment. Bioeng. 82: 299-305.

Rani, K., G. Dhania. 2014. Bioremediation and Biodegradation of Pesticide from Contaminated Soil and Water - A Noval Approach, Int. J. Curr. Microbiol. App. Sci. 3(10): 23-33

Rosliana, N., 2001. Bioremediasi Tanah Akibat Paparan Pestisida Klorpirifos. [Tesis]. Bandung: Magister Jurusan Teknik Lingkungan. Institut Teknologi Bandung.

Sani., Y., Indraningsih. 2007. Neuropatologi Keracunan Organofosfat pada Sapi, JITV, vol 12 no. 1. http://bbalitvet.litbang. deptan. go.id/ind/attacthments/217_7.pdf, diakses 2- Oktober 2012.

Setiyo, Y, Madew.S.Utama, Wayan TEkja dan I.B.P. Gunadya. 2011. Optimalisasi Proses Bioremediasi Secara In Situ psda Lahan Tercemar Pestisida Kelompok Mankozae, J. Teknik Industri. 12(1).
Singh BK dan Kuhad RC (2000) Degradation of the pesticidelindane by white-rot fungi Cyathus bulleri and Phanerochaete sordida. Pest Manag Sci. 56: 142-146.

Singh, B.K., Walker, A. 2006. Microbial degradation of organophosphorus compounds. FEMS Microbiol. Rev. 30: 428-471.

Sodiq, M. 2000 Pengaruh Pestisida Terhadap Kehidupan Organisme Tanah, J.Mapeta, vol. 2 No. 5, http://core.km.open.ac.uk/download/ df /12217742.pdf, diakses tanggal 17 Agustus 2014.

Stevens,T.J., Kilmer, R.I. 2009. Descriptive and Comparative analysis of Pesticide Residues Found in Florida Tomatoes and Strawberry, BUL331. http://edits.ifas. ufledu/11241, diakses tanggal 12 April 2011.

Sulistyaningsih, Minarti, S., Sjofjan, O., 2013, Tingkat residu pestisida dalam daging kelinci peranakan NewZealand White yang diberi pakan limbah pertanian kubis (Brassica oleracea). J. Ilmu-IImu Peternakan 23 (3):47 - 54.

Tarumingkeng, R.C., 1992, Insektisida : Sifat, Mekanisme Kerja dan Dampak Penggunaannya, Jakarta Universitas Kristen Krida Wacana.

Tuhumury, G.N.C., Leatemia,J. A., Rumthe,R.Y. dan. Hasinu,J.V. 2012. Residu Pestisida Produk Sayuran Segardi Kota Ambon, J.Agrologia, 1(2): 99-105.

Vidali, M. 2011. Bioremediation. An overview. Pure Appl. Chem. 73: 1163-1172.

Yang,C.; Liu, N.; Guo, X., Qiao, C. 2006. Cloning of mpd gene from a Chlorpyrifos degrading bacterium and use of this strain in bioremediation of contaminated soil. FEMS Microbiology Letter. 265:118-125.

Yasouri, F.N. 2006. Plasmid mediated degradation of diazinon by three bacterial strains Pseudomonas sp., Flavobacterium sp. and Agrobacterium sp.. Asian J. Chem. 18: 2437-2444. 